\title{
HUMAN BIOGEOGRAPHY AND FAUNAL EXPLOITATION IN DIAMANTE RIVER BASIN, CENTRAL WESTERN ARGENTINA
}

\author{
Clara Otaola ${ }^{1}$;iguel A. Giardina ${ }^{2}$ and Fernando R. Franchetti ${ }^{3}$
}

ABSTRACT. A biogeographic model used to describe human peopling of southern Mendoza, Central Western Argentina, proposed an intensification process activated by an increase in population growth rate during the Late Holocene. During this process, highranked resources at the surroundings of residential camps were depleted, and hunter gatherers broadened their diet by incorporating a larger number of low-ranked prey and domesticated plant resources. In this paper we evaluate an alternative hypothesis, focusing on zooarchaeological data from the Diamante River Basin. The results show that faunal resource intensification does not appear to have occurred in the Diamante River Basin during the late Holocene. Faunal consumption in Diamante River Basin mainly reflects the local fauna in each ecological zone. The data do not show a lack of higher ranked resources. We suggest it is more likely that the demographic increase was not significant enough to cause an impact on the faunal resources. The archaeological evidence should be improved and analyzed in smaller scales to continue with the intensification debate.

${ }^{1}$ Clara Otaola. CONICET-IANIGLA-UTN FRSR. claraotaola@ conicet.gov.ar

${ }^{2}$ Miguel A. Gardina. CONICET-IANIGLA-UTN FRSR. mgiardina@mendoza-conicet.gob.ar

Fernando R. Franchetti. Department of Anthropology. University of Pittsburgh. ferfranchetti@gmail.com

This article has been accepted for publication and undergone full peer review but has not been through the copyediting, typesetting, pagination and proofreading process which may lead to differences between this version and the Version of Record. Please cite this article as doi: $10.1002 / 0 a .2725$ 
KEYWORDS. Hunter Gatherers-Biogeography -Zooarchaeology-Intensification-Central Western Argentina-Diamante River Basin

\section{INTRODUCTION}

Land use by hunter-gatherers shapes subsistence and therefore different mobility strategies (Kelly, 1992). Central Western Argentina has patchy resources determined by a combination of arid and high elevation environments, commonly associated with the conditions of the arid diagonal that cross cuts South America transversally. Small scale groups had to manage uncertainties and changes in the variance of faunal distribution dependently of seasonality and primary productivity of different ecological zones. A biogeographic model proposed to explain human peopling of the southern Mendoza province (Fig. 1) suggests that during the Late Holocene, around 2000 years BP., changes in human demography produced a reduction in residential mobility. In this context of increased demography, people had to intensify the exploitation of several resources leading to the depression of the high-ranked ones in the surrounding areas of the residential camps (Neme, 2007; Neme \& Gil 2008a, b; Neme et al., 2012; Neme et al., 2015). Therefore, huntergatherers had to incorporate lowered ranked taxa into their diet due to the overhunting of guanacos (Lama guanicoe) (Neme, 2007; Neme \& Gil, 2008a; Neme et al., 2012; Neme et al., 2015). Llano et al. (2011) proposed the plant use increased during the period in which resource intensification purportedly accelerated. However, there is some archaeological evidence that does not match this model. Whether or not mobility declined deserves further discussion. Guanaco overhunting is not clear and plant use intensification in the Diamante River is not yet apparent (Gil et al., 2011; Ugan et al., 2012; Otaola et al., 2015; Wolverton et al., 2015). 
In this paper we test two alternative models related to the intensification process within a biogeographical perspective. The first hypothesis states that after an increase in population growth rate hunter-gatherers become more sedentary. This might cause the depletion of the high ranked resources and consequently a broader diet. The alternative hypothesis states that the increased demography did not cause people to become more sedentary, nor was the packing threshold reached, and an intensification of faunal resources did not occur. Although we need different archaeological evidence to robustly contrast both hypotheses, in this paper we are taking a preliminary zooarchaeological approach to Diamante River Basin Archaeology following the principles of optimal foraging models.

Within an evolutionary ecological perspective, Optimal Foraging Models are useful to address prehistoric hunter-gatherer decision-making (Stephen \& Krebs, 1986; Bettinger, 1991, 2009; Kelly, 1995; Bird \& O’Connel, 2006; Winterhalder, 1981). The applications of these models are particularly interesting in Central Western Argentina because of its diverse and patchy environments. The Diet Breadth Model allowed the discussion of the intensification model in this region (Neme, 2007; Neme \& Gil, 2008, Llano et al., 2011). The Diet Breadth Model predicts that high-ranked prey items will always be taken on encounter and that the less profitable resources will be added to the diet in descending rank order (MacArthur \& Pianka, 1966; Bird \& O’Connel 2006: 147). On the other hand, the Central Place Foraging Model states that foragers will choose to increase their rate of energy delivery to a central place by processing carcasses; therefore, leaving parts of low caloric utility at the kill sites (Orians and Pearson 1979, Cannon 2003; Metcalfe \& Barlow 1992; Nagaoka 2005; 2006). 
In Table 1, we present two possible scenarios describing two alternative hypotheses. For each hypothesis zooarchaeological implications are presented. In the intensification scenario human demography increases and the packing threshold is reached. With increased sedentism and the depletion of high ranked resources, lower ranked preys are incorporated in the diet. In this case, within the logic of the Central Place Foraging Model, foragers had to travel farther from central places to obtain higher ranked resources. This would have increased field processing time and only high ranked portions of carcasses would be expected in the recovered faunal material. Therefore, we assume a selective transport of anatomical units of high-ranked prey resources and a broader diet, including lower-ranked resources (Table 1). Bone fragmentation is also assumed to be high because foragers will expend more time extracting marrow and grease from bones (Fisher 2018; Outram 2002; Ugan 2005a).

In the non-intensification scenario, there is an increase in human demography, but the packing threshold is not reached. Residential mobility is not restricted; in this scenario there were enough places to move and resources were not depleted. Therefore, we expect the presence of high-ranked prey in the assemblages since there was not a decline in its availability. As it is not necessary to reduce the weight of the load to be transported to distant residential camps, all the skeletal parts of high-ranked prey would be present in the zooarchaeological record without a selection of the higher ranked items. Therefore, we expect to find all skeletal elements and the taxonomic diversity of each assemblage should be a reflection of local availability, since hunter gatherers are consuming what is in the surroundings of their camps. Bones should not be highly fragmented because foragers would be expending less time extracting nutrients from them (Table 1). To test either of these faunal expectations in the zooarcheological record, we explore aspects of faunal assemblages from the Diamante River Basin. 


\section{TABLE 1}

\section{AREA OF STUDY}

The Diamante River Basin extends from West to East crossing three main phytogeographic areas with altitudinal differences that influence vegetation and animal communities. These areas are the Altoandino, Patagonia and Monte deserts (Figure 1). From the morpho-climatic aspect, this region is highly variable because of its geographical relief, dominant masses of maritime air and rainy season. This area is exposed to anticyclones from the Atlantic and the Pacific Ocean. Influenced by Pacific anticyclones, the Andes belong to the Altoandino and Patagonia deserts, while the oriental plains, influenced by the Atlantic anticyclones, belong to the Monte Desert (Roig, 1972). Due to the distance travelled, the Atlantic winds produce low precipitation, while the winds from the Pacific precipitate at the mountain range of the Andes, arriving at this region as dry and warm winds (Abraham and Rodríguez, 2000; Norte, 2000). In the Monte Desert, most of the precipitation occurs in the summer, while in the Patagonia and Altoandino deserts, precipitation occurs mainly in the winter (Norte, 2000). Precipitation ranges from $200 \mathrm{~mm}$ in the Monte Desert to $1000 \mathrm{~mm}$ or more in the Upper Cordillera (Norte, 2000).

FIGURE 1 
Six of the archaeological sites analyzed in this paper are from the Patagonia Desert, and three in the Altoandino Desert (Figure 1). The Altoandino Desert is developed in a high mountain climate, cold and dry with frost all year round and rainfall in the form of snow in areas with an altitude above $2500 \mathrm{~m}$. The average annual temperature is lower than $8^{\circ} \mathrm{C}$ and the vegetation consists mainly of grassy steppes composed of Mulinum crassifolium species and Adesmia subterranea (Cabrera 1976, Roig 1972). The characteristic vegetal community is the coironal, with a predominance of Stipa, Festuca or Poa (Cabrera 1976). In this desert, during the summer months, the presence of springs is common (Roig 1972), offering food and water for animals. Human occupation in this region is only possible during warm seasons, at the end of the spring and summer.

The Patagonian Desert develops between 2300 and 1000 m., with a dry, cold climate and intense winds. The predominant vegetation is the shrub steppe, grasses, and cotyledons; grassy steppes are in the parts of greater humidity. The presence of some elements of Monte, mostly next to water streams or the river course marks an ecotone character between the phytogeographic provinces of Monte and Patagonia (Cabrera 1976). Human occupation in this region is possible throughout the whole year.

The faunal community in each of these deserts is mainly determined by primary productivity, which is related to the production of vegetal coverage. Variations in primary productivity have an important impact on human subsistence strategies (Kaplan and Hill 1992). This will vary not only with the levels of annual precipitation but also with the capacity of the soils to retain water (Rosenzweig 1968). Evapotranspiration and water percolation can negatively affect primary productivity. Even though the Altoandino desert has a higher annual precipitation than the Patagonian Desert, the water is retained only in those areas such as springs, places that are very attractive to animals and humans. 
Although there is not a strict correlation between altitude and diversity (Mc Cain and

Grytnes 2010; Rahbek 1995), there exists a general pattern of declining species richness of flora and fauna with increasing altitude (Pianka 1982). This is also observed in zoological and botanical studies made in our area of study (Roig 1972; Roig et al. 2000; Videla et al. 1997). In the Altoandino desert fauna is present from 2300 masl till the vegetation disappears at 4000 masl (Roig 1972). There are large mammals such as puma (Felis concolor) and guanaco (Lama guanicoe); medium sized mammals such as red fox (Pseudalopex culpaeus), and small mammals such as small rodents (Akodon andinus, Ctenomys mendocius and Phyllotis darwini). In areas with springs and in Laguna del Diamante Lake, there are also aquatic birds.

Within the Patagonian Desert, below 2300 masl, guanaco and puma are still the largest sized mammals present, but the red fox is replaced by the grey fox. In this area we can find medium sized rodents such as chinchillón (Lagidium viscaccia) and Vizcacha (Lagostomus maximus), and other rodents of small size (less than $1 \mathrm{~kg}$. ), like Tuco-Tuco (Ctenomys mendocinus). There also live edentates, such as Chaetophractus villosus and Zaediyus pichiy, carnivores such as the wildcat (Felis geoffroyi) and the skunk (Conepatus chinga). In addition there lives a large number of birds, among the most important we find the Rheidae, which are located in well-defined niches living in this ecological zone (Roig 1972). It is also possible to find saurians, among which we find batrachians and reptiles. Two fish species are native from this area: Pygidium borelli and Hatcheria sp. (Roig 1972). Despite this large list of available native species, the archaeological record is dominated by guanacos, edentates, and large sized rodents such as Patagonian Mara, Chinchilla and Vizcacha. 
Faunal resources in the middle (Patagonia dessert) and upper basin (Altoandino desert) are distributed heterogeneously in the landscape. Due to the lack of optimal conditions for the generation of soils and moisture to let vegetation grow continuously, these deserts present a patchy distribution of resources. There are differences in the time they where first occupied and the way in which people take advantage of the available resources. Patagonia sites have been occupied since the beginning of the early Holocene, with exploitation of local resources by highly mobile hunter-gatherers (Giardina et al. 2017). Altoandino sites were occupied later, around 1000 years B.P. as residential bases of hunter gatherers focused on hunting of guanacos. Sites were occupied for several weeks during summer seasons, when these highlands areas are without snow cover and guanacos also migrate to those areas (Neme 2007, Neme et al. 2017; Morgan et al. 2017).

\section{ARCHAEOLOGICAL SITES AND METHODOLOGY}

For this analysis, we consider zooarchaeological samples from nine archaeological sites that date to the Late Holocene in the Diamante River basin. None of these sites have been defined as special purpose sites (Neme 2007, Neme et al. 2016, Giardina et al., 2017, Morgan et al., 2017). These include Altoandino desert open air sites that date from 1500 to $500 \mathrm{BP}$; El Indígeno, Risco de los Indios and Laguna del Diamante-4 which present unique features within the region (Table 1 supplementary material). Their main characteristics are the presence of semicircular-housing structures built with local rocks and a higher frequency of pottery (Durán et al. 2006; Neme et al., 2016; Morgan et al., 2017). They are located near springs and lakes, which form attractive patches for aquatic and terrestrial fauna. There is a strong presence of non-local materials that denotes contact between populations from both sides of the Andes. These sites have been defined as residential sites with prolonged summer 
residence, as these locations are inaccessible during winter due to the snow cover (Neme et al., 2016; Morgan et al., 2017).

The other archaeological sites included in this analysis come from the Patagonian Desert from both the Early and Late Holocene occupation periods. For the purpose of this research, we are focusing on the range of dates from 2200 to $500 \mathrm{BP}$, as this is the time frame proposed for the intensification process (Table 1 supplementary material). These sites are located in caves, except for El Perdido 4 and 5, which are open air sites that lack structures. In the assemblages from the cave sites, there is evidence for the consumption of domestic and wild plants (Giardina et al. 2017).

\section{Faunal Variables analyzed}

The variables used to test the zooarchaeological expectations for each hypothesis are related to taxonomic composition, guanaco butchering, and transport behavior.

We studied the taxonomic structure of the assemblages by considering taxonomic richness and estimating NTAXA at family level. Using these criteria, we avoid misrepresentation in taxonomic richness due to differential fragmentation (Grayson 1984; Lyman 2008). We noticed that some taxa entered the zooarchaeological assemblages as a consequence of natural processes as a product of animal activity which affects the taxonomic composition of the assemblages (Giardina, 2010). These remains were not included in the analyses. Importantly, we observe a strong and positive relation between sample size and NTAXA $\left(R^{2}=0.95 ; \mathrm{p}<0.01\right)$. This means that the number of species found in each site might be driven by the size of the samples. For this reason, our focus is on dietary evenness as measured using Simpson's 1/D, following the formula $1 / \sum \mathrm{n}_{i}\left[\mathrm{n}_{i^{-}}-1\right] / \mathrm{N}[\mathrm{N}-1]$; because this index is less sensitive sample size effects than other diversity indices (Lyman 2008:196). 
Greater values represent increased evenness in an assemblage, showing the broadening of the diet.

The profitability of a prey species depends on two factors: the number of calories they contain and the handling cost. So, the net rank of a species consists of its caloric value minus its handling cost (Dusseldorp 2010). Before Corbat's work (2016), prey species were ranked following the logic that larger animals provide a greater number of calories than smaller ones (Broughton 1994a, 1994b; Nagaoka2001, 2002; Ugan 2005b). However, there are many fauna, which when considering handling costs, have returns that are negatively correlated with carcass size meaning that in some cases "bigger is not better" (Lupo and Schmitt, 2016, Stiner et al. 1999; Stiner and Munro 2002). The Prey Rank Model made for Central Western Argentina exhibits something like this. Armadillos (Zaedyus pichiy, Chaetophractus villosus and Chaetophractus vellerosus), with a body weight around 1 to $3 \mathrm{~kg}$, are among the smallest prey animals, but they are easy to capture and have relatively low handling costs, making their net return high (Otaola et al., 2015b; Corbat et al. 2016). Rheidae eggs are also easy to obtain when they are available in the spring season (del Hoyo et al., 1992) and have low handling cost. Rhea are one of the largest animals present in the area, giving about $14 \mathrm{~kg}$ of meat and fat per animal, but they are very difficult to capture (Giardina 2018). We estimate if the highest-ranked prey were present in the assemblages taking Corbat (Corbat et al. 2016) rank order into account. Other indices used to assess the structure of the assemblages were NISP proportion of guanaco remains (pGUA, Otaola et al., 2015).

Studies in prey demography had been carried out using a broader spatial scale, considering assemblages that can be analyzed diachronically to assess the availability of guanaco and if they were depleted, (Neme et al. 2012). Unfortunately, in most of the assemblages from the Diamante River Basin, we did not have fine-grained chronological information available for these types of analyses. In the sites expressing better chronological 
information, guanaco samples are not large enough. However, we were able to test guanaco butchering, transport and consumption strategies, as a proxy of how intense guanacos had been exploited and if they were transported to the residential camps from afar.

The relationship of economic utility and skeletal parts present at a site has been used ethnographically to analyze strategies of prey transport from kill sites to residential bases (Binford, 1978; Bird et al., 2009; Lupo, 2001; 2006, 2007; O`Connell et al.,1990). The expectation from foraging theory suggests foragers will travel farther when large game decline, resulting in a greater selective transportation to central camps. We made Spearman's rank order correlations between meat utility index (MUI) and marrow index (MI) values of guanaco and the normed NISP (NNISP) to identify skeletal part transportation decisions (Borrero, 1990, Mengoni Goñalons 1996). Importantly, when considering the different utility indices, we first studied the correlation between the skeletal part representation and mineral bone density of guanacos (Lyman 1984; Stahl, 1999). We observed the degree of densitymediated attrition by using Spearman's rank correlation between bone survival in terms of NNISP and published volume density values (Stahl, 1999). We analyzed the intensity of fragmentation looking at the ratio of NISP to MNE of guanaco bones and the median of NISP:MNE, only considering bones with high content of bone grease (Binford 1978). High NISP per MNE implies intense fragmentation (Lyman 1994; Wolverton 2002).

\section{RESULTS.}

All the assemblages from our study exhibited presence of guanaco, the highest ranked prey. In the Altoandino desert, the zooarchaeological record is mainly composed by local fauna, which includes guanaco, red fox and aquatic birds (Table 2). These resources are also partially complemented with non-local ones such as armadillos, ostrich eggs, and domestic and wild plants from lower altitudinal floors (Durán et al., 2006; Neme et al., 2016). In the 
Patagonia desert, in addition to the guanaco and red fox that belongs to both elevations, we observe grey fox, a great amount of Rheidae eggshell, medium sized rodents like chinchillón and vizcacha, and edentates such as armadillos. Another large animal found in these sites is the puma, whose distribution also corresponds to both deserts; Altoandino and Patagonia (Table 2).

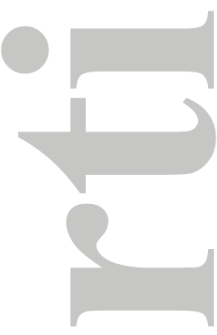

\section{TABLE 2}

The NTAXA index demonstrates a larger number of prey exploited in LD-S4 and Alero Montiel. Each of these assemblages showed the faunal availability of their surroundings. LD-S4 faunas are composed by taxa that are also present in Patagonian desert but with the addition of aquatic birds from Laguna del Diamante. Alero Montiel, located in the Patagonia Desert, has a great amount of terrestrial fauna that inhabit the Patagonian desert. Table 3 shows the results of the NTAXA analyses and which taxa are present in each assemblage at family level. We observe that assemblages with lower NTAXA like El Indigeno and RI in Altoandino desert and C. Manantial, EP5, EP4 and Potrerillos in Patagonia are nested in the assemblages with higher NTAXA (Table 3).

\section{TABLE 3.}

Guanacos (Camelidae) are present in all the assemblages and are the dominant faunal resource in most of them, as it can be observed by the pGUA index. Hence, the Simpson's index (1/D) shows very low values (Figure 2). There is not a statistically significant difference among the Altoandino samples and the Patagonian samples (Kruskall wallis test for medians of pGUA; 
$\mathrm{H}=0.26 ; \mathrm{p}=0.6$ and of $1 / \mathrm{D}$ index; $\mathrm{H}=0.6 ; \mathrm{p}=0.42)$. In the Altoandino desert, Guanacos predominate all the assemblages, with high values of pGUA and low values of simpson's eveness index (Figure 2). In the Patagonia desert, there is more variability among assemblages, sites have both high and low values of pGUA.

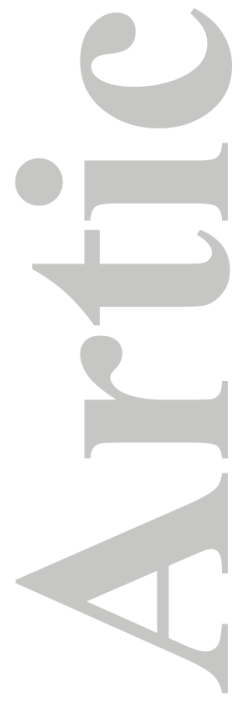

FIGURE 2

Even in small samples, guanaco tend to be the most represented taxon. Three assemblages from the Patagonia desert (El Perdido 4; El Perdido 5 and Carrizalito) have NISP of Camelidae equal or less than 10; for this reason we decided to exclude them from the following analyses and establish comparisons among three sites from Altoandino and three sites from Patagonia desert.

Correlation among element frequencies and mineral bone density was not strong in almost all the assemblages. Only Risco de los Indios had a positive correlation, indicating that preservation is not good at this site. In cases like this, we infer that the assemblage suffered heavy attrition and is biased. The correlation between \%NISP and Meat and Marrow index shows that the assemblages do not have a strong relation between food utility and skeletal representation. Regarding guanaco bone grease extraction, fragmentation in all the cases was not high, as is indicated by the low values of the ratios of NISP to MNE (Table 4). 


\section{TABLE 4}

In summation, in the Diamante River Basin, we did not find evidence of depression of the highest ranked resources. Guanacos and armadillos, the higher ranked prey, are well represented in the assemblages. In addition, low ranked prey are present in all of the assemblages across ecoregions. We infer that this is not related to scarcity in the higher ranked prey items, but to the exploitation of areas with specific resources such as Laguna el Diamante, and areas where springs are located, such as Risco de los Indios and El Indígeno. We observe the same trend at the Patagonia Desert. There is at least one site, Alero Montiel, with a great number of taxa consumed, independently of higher ranked prey availability. It is important to remember that those sites with a greater NTAXA are also some of the sites with the bigger sample size, showing that sample size affects the estimation of animal species consumed in each of these assemblages. However, for each desert, the sites with lower NTAXA are nested in the assemblages with higher values of this index. This shows that, even though sample size affects NTAXA, the samples might have been derived from the same underlying population (see Lyman 2008: 167).

In addition, from the analyses of skeletal profiles in guanacos, we observed bone elements of different economic utility. This might not be caused by differences in bone preservation, except for Risco de los Indios that had a positive correlation between NISP and bone mineral density.

\section{DISCUSSION AND CONCLUDING REMARKS}

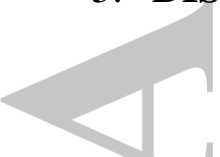

The faunal analyses presented in this paper are discussed within a biogeographic perspective and pivoting the intensification concept, which was broadly approached in 
several research projects of Central Western-Argentina (Neme \&Gil 2008; Neme et al. 2015; Otaola 2012; Otaola et al. 2013, 2015; Wolverton et al. 2015). Morgan (2015) proposes that the intensification concept should be used following a strict "Boserupian" definition which entails declining foraging efficiency, understood as the increase in total productivity per unit of time and space (i.e. Boserup 1965; Broughton 1999). In this region, intensification was used to explain how people solve population resource imbalances by the addition of more labor and a decreased foraging efficiency, an approach similar to Boserup's and stated in the scenario proposed in table 1 (Neme 2007; Neme et al. 2015). In a finer resolution, Llano et al. (2011) proposed plant use intensification focusing at Diamante River Basin. However, we find several problematic issues in how the archaeobotanical data were interpreted. The authors argued that the archaeobotanical evidence shows the broadening of the diet with the incorporation of lower ranked vegetal taxa in the last 1500 years. However; some of those specimens were used to make artifacts (Llano et al., 2011; Llano, 2014:101) and some of the archaebotanical samples used to argue in favor of the intensification model come from stratigraphic units without a clear chronological assignation (Llano, 2010:356). Even though the findings on how botanical resources had been used are very valuable to understand hunter-gatherers' adaptations at Diamante Basin, their chronology is not confident enough to put them in the intensification debate.

Regarding the faunal analyses in Diamante River Basin, the patterns found here contrast with the patterns of intensification among hunter-gatherers in other parts of the world. In all those cases, low ranked prey were incorporated to the diet in association with a decrease in large sized prey (Broughton 1994b; 1997; 1999; Buttler \& Campbell 2004; Janetski 1997; Quintana \& Mazzanti 2014; Stoessel 2014; Tívoli \& Zangrando 2011). Other modes of increasing production such as diversification, specialization and innovation, which do not necessarily entail a decreased in foraging efficiency, should not be 
defined as intensification. Our research showed that zooarchaeological assemblages from Diamante River Basin do not clearly exhibit a decrease in foraging efficiency, since the high ranked resources are always dominant in the assemblages.

These zooarchaeological evidences match better with the expectations of the nonintensification scenario presented in Table 1. The analyses from both deserts did not show significant differences among the results. High-ranked faunal resources are present in all the assemblages and there is not a special strategy for body part transport. In addition, we did not find evidence for guanaco overexploitation, nor was their exploitation being intensified in any of the areas. The presence of lower ranked prey in the assemblages studied here, are part of a strategy of exploitation of fauna available in the areas surrounding the occupied sites.

Our vision of how people take advantage of the faunal resources in Diamante River Basin is not framed within an intensification process because we observed that these faunal exploitation strategies might not necessarily have implied a decrease in foraging efficiency. However, to improve the feasibility of intensification, we need to generate data in settlement patterns, land use, packing threshold and demography. Additionally, we need to test the hypothesis of a reduction in residential mobility and development of territoriality as it was previously stated (Neme, 2007). A smaller scale study on isotopic analyses using samples from Diamante River Basin is already being considered to test the hypothesis of changes in residential mobility during the Late Holocene.

\section{AKNOWLEDGEMENTS}

A previous version of this paper was presented in the $4^{\circ}$ Congreso Nacional de Zooarqueología, Ushuaia, Argentina. We want to thank the organizers of that meeting for letting us do that presentation. We would also like to thank Gil Family, a group of 
contemporary ranchers that live in Diamante River Basin and help with the field work. We also thank to Laura Steele and James Grabiak who helped with English edits.

Agencia Nacional de Promoción Científica y Tecnológica, FONCYT. PICT 2015-3707 gave the financial support for this research.

No conflict of interests.

Authors contribution:

Conception and design - $\mathrm{CO}$ and MG

Field Work to obtain data: $\mathrm{MG}, \mathrm{CO}$ and FF

Processing data: $\mathrm{MG}$ and $\mathrm{CO}$

Statistical analysis of data: $\mathrm{CO}$; MG and FF

Writing and reviewing the manuscript: $\mathrm{CO}, \mathrm{MG}$ and $\mathrm{FF}$

\section{REFERENCES}

Abraham, EM., 2000. Geomorfología de la provincia de Mendoza. In: Abraham, M.,

Rodríguez Martínez, F. (Eds.), Recursos y problemas ambientales de zonas áridas.

Primera parte: provincias de Mendoza, San Juan y La Rioja, Caracterización

ambiental I. IADIZA, Mendoza, pp. 29-48.

Bettinger, R., 1991. Hunter-Gatherers: Archaeological and Evolutionary Theory.

Plenum, New York.

2009. Hunter-Gatherer Foraging: Five Simple Models. E.Welmer publications: New York Press, Berkeley. 
Bird D., O’Connel, J.F. 2006 Behavioral Ecology and Archaeology. Journal of Archaeological Research 14: 143-188

Bird, D., Bird, R., Codding, B. 2009. In Pursuit of Mobile Prey: Martu Hunting Strategies and Archaeofaunal Interpretation. American Antiquity, 74(1), 3-29.

doi:10.1017/S000273160004748X

Binford, L. R. 1978. Nunamiut ethnoarchaeology.Academic Press, New York.

2001. Constructing Frames of Reference: An Analytical Method for Archaeological Theory

Building Using Hunter-Gatherer and Environmental Data Sets. University of California

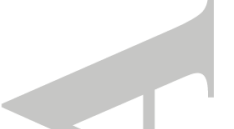

Borrero L. 1990. Fuego-Patagonian bone assemblages and the problem of communal guanaco hunting. In: Hunters of the Recent Past. Editado por: L. B. Davis y B. O. K. Reeves, pp. 373399. Londres, Unwin Hyman.

Boserup, E. 1965. The Conditions of Agricultural Growth, Aldine, Chicago.

Broughton JM. 1994a. Declines in mammalian foraging efficiency during the late Holocene, San Francisco Bay, California. Journal of Antrhopological Archaeology 13: 371-401.

1994b. Late Holocene resource intensification in the Sacramento Valley, California: the vertebrate evidence. Journal of Archaeological Science 21, 501-514.

1997. Widening diet breadth, declining foraging efficiency, and prehistoric harvest pressure: ichthyofaunal evidence from the Emeryville Shellmound, California. Antiquity 71, 845-862.

1999. Resource Depression and Intensification during the Late 
Holocene, San Francisco Bay: Evidence from the Emeryville Shellmound Vertebrate Fauna. University of California Press, Berkeley.

Cabrera, A.L., 1976. Regiones fitogeográficas argentinas. Encicl. Argent. Agric. Jard. 1 pp.185.<smiles>C1CCC2CCCC2CC1</smiles>

Cannon, M. 2003. A model of central place forager prey choiceand application to faunal remains from the Mimbres Valley,New Mexico. Journal of Anthropological Archaeology 22: $1-25$.

Corbat, M. 2016. Variabilidad ambiental y sociocultural en la explotación de peces en el centro-occidente argentino: una evaluación zooarqueológica. Tesis doctoral inédita.

Universidad de Buenos Aires, Facultad de Filosofía y Letras

Corbat, M. A. Gil, F. Zangrando 2016.Ranking de recursos y el rol de los peces en las dietas Humanas del Centro Occidente Argentino. Trabajo presentado en el IV Congreso Nacional de Zooarqeuologia Argentino, Ushuaia.

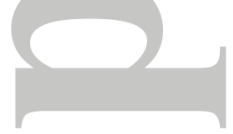

Durán, V., Neme, G., Cortegoso, V., Gil, A., 2006. Arquelogía del Area Natural ProtegidaLaguna del Diamante (Mendoza, Argentina). Anales de Arqueologìa y Etnologìa 61. 81-134.

Dusseldorp, G. L. 2010. Prey choice during the South African Middle Stone Age: avoiding dangerous prey or maximising returns? African Archaeological Review, 27(2), 107-133. 
Fisher, J.L.2018. Protohistoric artiodactyl rebound and resource deintensification in northern

California. Journal of Archaeological Science: Reports 19 (2018) 420-429

Giardina, M. 2010. El aprovechamiento de la avifauna entre las sociedades cazadoras-

recolectorasdel sur de Mendoza: un enfoque arqueozoológico (unpublished

doctoral disertation). Facultad de Ciencias Naturales y Museo,Universidad Nacional La Plata.

2018. Economic anatomy of Rheidae and its implication for the archeological record.

Archaeological and Anthropological Sciences. Article in press.

https://doi.org/10.1007/s12520-018-0659-X

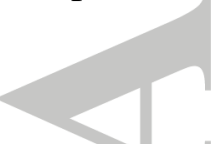

Giardina, M., Otaola, C., Franchetti, F. 2017. Biogeografía humana en la cuenca del Río Diamante: información arqueológica y perspectivas. Revista del Museo de Antropología, UNC 10, 21-32.

Gil A, Neme G, Ugan A, Tykot R. 2011b. Oxygenisotopes and human mobility in centralwestern Argentina.International Journal of Osteoarchaeology. DOI: 10.1002/
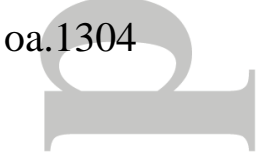

Grayson, D K. 1984. Quantitative Zooarchaeology. Topics in the Analysis of Archaeological Faunas.Orlando, Academic Press. 16 (6): 643-652.

1989. Sample size and relative abundance inarchaeological analysis: Ilustration from spiral fracturesand seriation. Quantifying Diversity in Archaeology, R Leonard, G Jones (eds.). Cambridge University Press:Cambridge; 79-84. 
Gil, A., Giardina, M., Neme, G., Ugan, A. 2014. Demografía humana e incorporación de cultígenos en el centro occidente argentino: explorando tendencias en las fechas radiocarbónicas/Human Demography and Domestic Plants in Central Western Argentina: Exploring Trends in Radiocarbon Dates. Revista Española de Antropología Americana, 44(2), 523-553

Janetski, Joel C., 1997. Fremont hunting and resource intensification in the eastern GreatBasin. J. Archaeol. Sci. 24, 1075-1088.

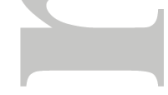

Llano. C., Neme G., Michieli C. 2012. Plant use intensificationamong hunter-gatherers in the Diamante river basin,Argentina. Before Farming 2011/2.

Llano,C. 2010. Aprovechamiento de los Recursos vegetales entre las sociedades cazadoras-recolectores del Sur de Mendoza (unpublished doctoral disertation).

Universidad Nacional del Comahue, San Carlos de Bariloche.

-2014. La explotación de los recursos vegetales en sociedades cazadoras-recolectoras del sur de Mendoza, Argentina. DARWINIANA, nueva serie 2(1): 96-111. DOI:

10.14522/darwiniana.2014.21.549

Lupo, K.D. 2001. On the archaeological resolution of body part transport patterns: An ethnoarchaeological example from East African hunter-gatherers. Journal of Anthropological Archaeology 20 (3): 361-378.

2006 What Explains the Carcass Field Processing and Transport Decisions of Contemporary Hunter-Gatherers? Measures of Economic Anatomy and Zooarchaeological Skeletal Part Representation. Journal of Archaeological Method and Theory 13 (1): 19-66. 
2007 Evolutionary Foraging Models in Zooarchaeological Analysis: Recent applications and Future Challenges Journal of archaeological research, 15: 143-189.

Lupo, KD., Schmitt, DN. 2016. When bigger is not better: the economics of hunting megafauna and its implications for Plio-Pleistocene hunter-gatherers. Journal of Anthropological Archaeology, 44, 185-197.

Lyman, RL.1984. Bone density and differential survivorship of fossil classes. Journal of Anthropological archaeology, 3(4), pp.259-299.
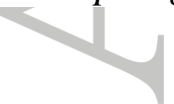

1994. Relative abundances of skeletal specimens and taphonomic analysis of vertebrate remains. Palaios, 288-298

2008 Quantitative Paleozoology. Cambridge manuals in Archaeology. Cambridge University Press, New York.

Macarthur, RH., Pianka ER. 1966. On Optimal use of a patchy environment . The American Naturalist. Vol 100: 603-609. Publicado por The University of Chicago Press para The American Society of Naturalists.

McCain, C. M., \& Grytnes, J. A. 2010. Elevational gradients in species richness. eLS. 
Metcalfe, D., \& Barlow, K. R. 1992. A model for exploring the optimal trade- off between field processing and transport. American Anthropologist, 94(2), 340-356.

Nagaoka, L., 2001. Using diversity indices to measure changes in prey choice at the

Shag River Mouth Site, Southern New Zeland. Int. J. Osteoarchaeol. 11, 101-111.

2002. The effects of resource depression on foraging efficiency, diet

breadth, and patch use in southern New Zealand. J. Anthropol. Archaeol. 21,

$419-442$

Nagaoka, L., 2005. Declining foraging efficiency and moa carcass exploitation in southern New Zealand. Journal of Archaeological Science, 32(9), pp.1328-1338.

Nagaoka, L., 2006. Prehistoric seal carcass exploitation at the Shag Mouth site, New Zealand. Journal of Archaeological Science, 33(10), pp.1474-1481.

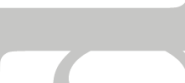

Neme G. 2007. Cazadores-recolectores de altura en los Andes meridionales: El alto valle del río Atuel. British Archaeological Reports International Series: 1591.

Neme G, Gil A. 2008a. Faunal exploitation and agricultural transitions in the South American agricultural limit. International Journal of Osteoarchaeology 17: 1-15.

2008b. Biogeografía humana en los Andes meridionales: tendencias arqueológicas en el sur de Mendoza. Chungará 40 (1), 5-18.

Neme G, Gil A. 2012. El registro arqueológico del sur de Mendoza en perspectiva biogeográfica. Paleoecología Humana en el sur de Mendoza: Perspectivas Arqueológicas, G Neme, A Gil (comps.). Sociedad Argentina de Antropología: Buenos Aires; 255-279. 
Neme G, Wolverton S, Gil A. 2012. Modelo ecológico para evaluar la sobreexplotación de

Ungulados: implicancias en los conjuntos zooarqueológicos de guanaco del sur de

Mendoza. Archaeofauna, (21)

Neme, G., Gil, A., Otaola, C., Giardina, M., 2015. Resource structure and human

mobility: trends in the archaeofaunal record from central western Argentina.

International Journal of Osteoarchaeology. Vol 25 (6) 866-876.

http://dx.doi.org/10.1002/oa.2359.

Neme, G., Sugrañes, N., Salgán, L., Gil, A., Otaola, C., Giardina, Llano, C. 2016. Risco de los Indios: ocupaciones humanas de altura en la cuenca del río Diamante. Relaciones de la Sociedad Argentina de Antropología, 41.

$r$

Norte, F., 2000. Mapa climático de Mendoza. In: Abraham, E.M., Martinez, F.R. (Eds.),En Argentina. Recursos y problemas ambientales de la zonas áridas. Provincias deMendoza,

San Juan y La Rioja, Caracterización ambiental I, pp. 25-27

Mengoni Goñalons, GL. 1996. La domesticación delos camélidos sudamericanos y su anatomía económica.In: Zooarqueología de Camélidos. Perspectivasteóricas y

metodológicas: 33-45. Grupo Zooarqueología de Camélidos, Buenos Aires.

Metcalfe, D., \& Barlow, K. R. (1992). A model for exploring the optimal trade- off between field processing and transport. American Anthropologist, 94(2), 340-356. 
Morgan, C. 2015. Is it intensification yet? Current archaeological perspectives on the evolution of hunter-gatherer economies. Journal of Archaeological Research, 23(2), 163-213.

Morgan, C., Neme, G., Sugrañes, N., Salgan, L., Gil, A. F., Otaola, C., \& Llano, C. (2017).

Late Prehistoric High-Altitude Hunter-Gatherer Residential Occupations in the Argentine Southern Andes. Journal of Field Archaeology, 42(3), 214-227.

Kaplan H., Hill K. 1992. The evolutionary Ecology of Food Acquisition. En Evolutionary

Ecology and Human Behaviour, pp.167-202. Editado por E. A. Smith y B. Winterhalder. Walter de Gruyter, Nueva York.

Kelly RL. 1992. Mobility/sedentism: concepts, archaeological measures, and effects. Annual Review of Anthropology, 21(1), 43-66.

-1995 The foraging spectrum. Diversity in hunter gatheresrs lifeways. Smithsonian institution press. O Connel et al 1990

Otaola, C., Wolverton, S., Giardina, M.A., Neme, G. 2015. Geographic scale and zooarchaeological analysis of Late Holocene foraging adaptations in western Argentina. Journal of Archaeological Science, 55, 16-25.

Outram, Alan K., 2002. Identifying dietary stress in marginal environments: bone fats, optimal foraging theory and the seasonal round. In: Mondini, M., Muñoz, S., Wickler, S. (Eds.), Colonisation, Migration and Marginal Areas: A Zooarchaeological Approach. Oxbow Books, Oxford, pp. 74-85 
Orians, GH, Pearson NE- 1979. On the theory of central place foraging. In: Analysis of ecological Sistem, Editado por David J. Horn y R.D. Mitchell y G.R. Stairs, pp.154-177. The Ohio State University Press, Columbus.

Pianka, E. R., \& Ayala, J. (1982). Ecología evolutiva (Vol. 365). Barcelona: Omega.<smiles>C1CCC1</smiles>

Quintana, C. A., \& Mazzanti, D. L. (2014). La emergencia de la diversificación de la caza en las sierras de tandilia oriental durante el holoceno tardío final. Comechingonia, 18(2), 41-64.

Rahbek, C. (1995). The elevational gradient of species richness: a uniform pattern?. Ecography, 18(2), 200-205.

Roig, F.A., 1972. Bosquejo fisionómico de la vegetación de la provincia de Mendoza. Bol. Soc. Argent. Bot. 49-80.

Roig, F.A., Martínez Carretero, E., Méndez, E., 2000. Mapa de vegetación de la Provincia de Mendoza. In: Abraham, M.E., Rodríguez Martínez, F. (Eds.), Recursos y problemas ambientales de zonasáridas CRICYT, Mendoza, p. 10.

Rosenzweig ML. 1968. Net Primary Productivity of Terrestrial Communities: Prediction from ClimatologicalData

The American Naturalist, Vol. 102, No. 923 (Jan. - Feb., 1968), pp. 67-74

Stephens, DW., Krebs JR.1986.Foraging theory. Princeton Univ. Press,Princeton. 
Stahl, PW. 1999.Structural Density of Domesticates South America Camelid Skeletal Elements and the Archaeological Investigation of Prehistoric Andean Ch'arki. Journal of Archaeological Science 26 :1347-1368.

Stiner, MC. 2002. On in situ Attrition and Vertebrate Body Part Profiles. Journal of Archaeological Science 29 : 979-991.

Stiner, M. C., \& Munro, N. D. 2002 . Approaches to prehistoric diet breadth, demography, and prey ranking systems in time and space. Journal of Archaeological Method and Theory, 9(2), 181-214.

Stiner, M. C., Munro, N. D., Surovell, T. A., Tchernov, E., \& Bar-Yosef, O. (1999).

Paleolithic population growth pulses evidenced by small animal exploitation. Science, 283(5399), 190-194.

Stoessel, L. 2014. Evaluating intensity in the processing of guanaco (Lama guanicoe) at the lower basin of the Colorado river (Argentina): fragmentation levels and fracture patterns analysis. International Journal of Osteoarchaeology, 24(1), 51-67.

Tivoli, A. M., \& Zangrando, A. F. (2011). Subsistence variations and landscape use among maritime hunter-gatherers. A zooarchaeological analysis from the Beagle Channel (Tierra del Fuego, Argentina). Journal of Archaeological Science, 38(5), 1148-1156.

Ugan, A., 2005a. Climate, bone density, and resource depression: what is driving variationin large and small game in Fremont archaeofaunas? J. Anthropol. Archaeol. 24,227-251. 
Ugan, A. 2005b. Does size matter? Body size, mass collecting, and their implications for understanding prehistoric foraging behavior. American Antiquity, 70(1), 75-89.

Ugan A, Neme G, Gil A, Coltrain J, Tykot R, Novellino P.2012. Geographic variation in bone carbonate and water ${ }^{18} \mathrm{O}$ values in Mendoza, Argentina and their relationship to prehistoric economy and settlement. Journal ofArchaeological Science 39: 2752-2763.

Videla, F., Rosi, M., Puig, S., \& Cona, M. 1997. Vertebrados de Mendoza y sus adaptaciones al ambiente árido. Inca. Mendoza.

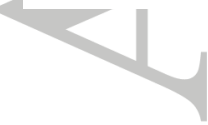

Winterhalder, B. (1981). Optimal foraging strategies and hunter-gatherer research in anthropology: Theory and models. In : Hunter-gatherer foraging strategies: Ethnographic and archaeological analyses, pp. 13-35. University of Chigcago Press. Chicago

Wolverton, S., Otaola, C., Neme, G., Giardina, M., Gil, A. 2015. Patch Choice, Landscape Ecology, and Foraging Efficiency: the Zooarchaeology of Late Holocene Foragers in Western Argentina. Journal of Ethnobiology, 35(3), 499-518. 


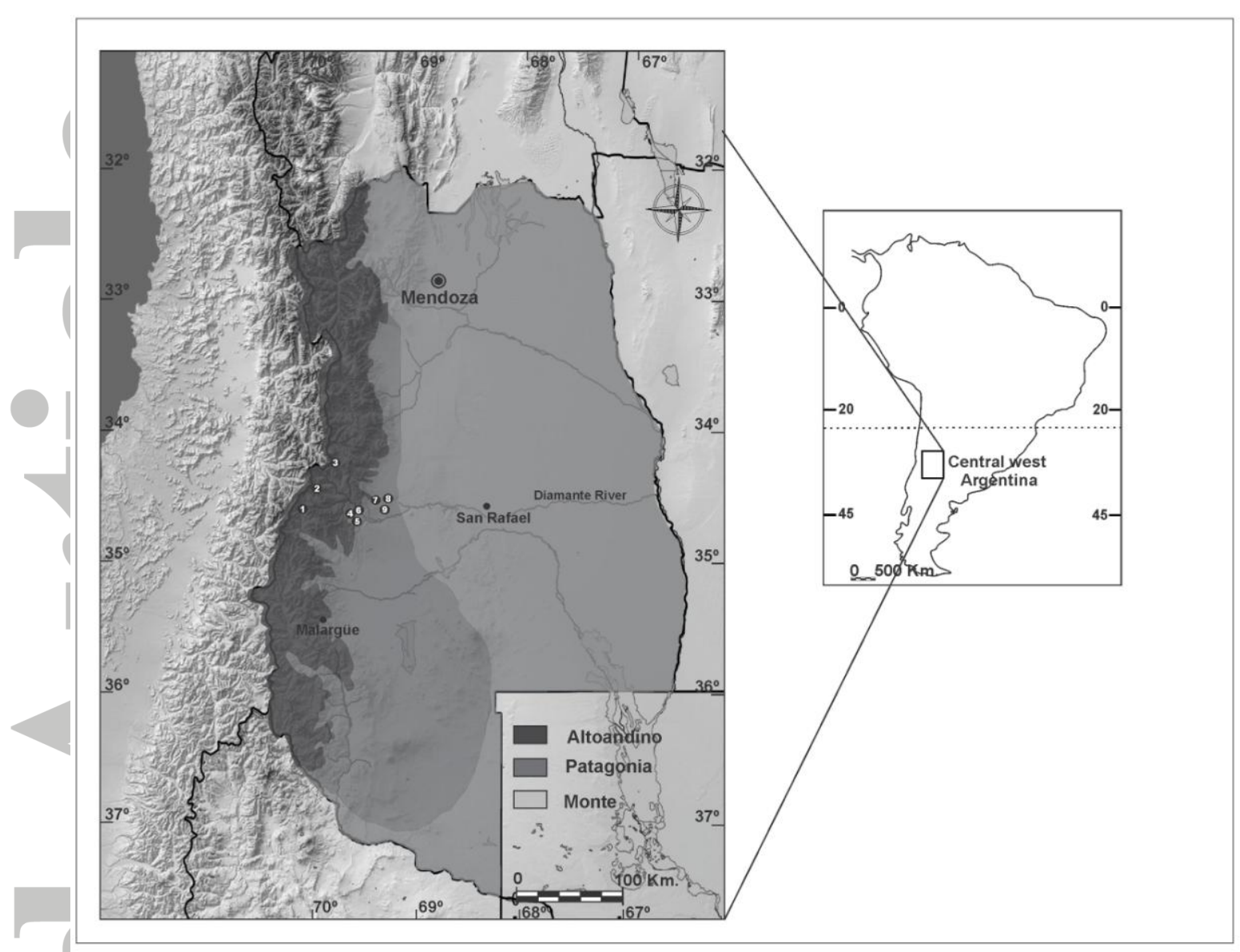

Figure 1. Archaeological sites considered in this paper and main phytogeographic deserts.1. El Indigeno, 2: Risco de los Indios; 3. Laguna del Diamante-4; 4.El Perdido 4; 5. El Perdido 5; 6. Cueva el Manantial; 7 Carrizalito; 8. Alero Montiel; 9. Potrerillos. 


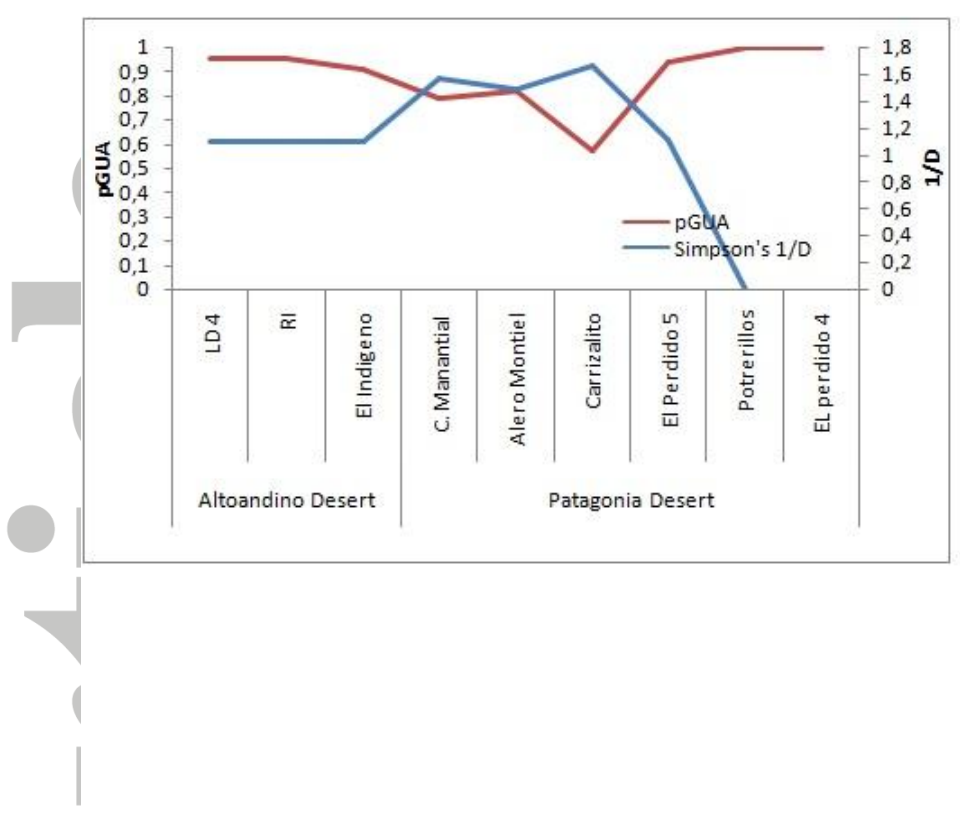

Figure 2: Simpson's 1/D and proportion of guanaco (pGUA) indices. Assemblages are grouped according to its location in Altoandino or Patagonia desert.

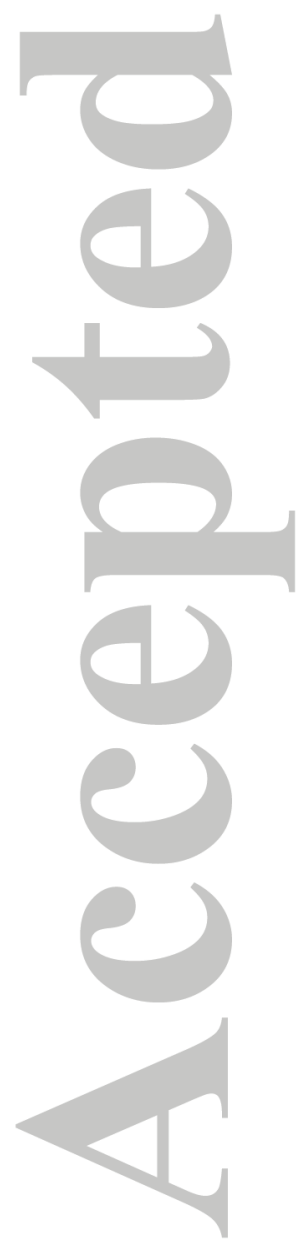


Table 1 Two alternative hypotheses and the zooarchaeological expectations for Diamante River Basin assemblages.

\begin{tabular}{|c|l|l|l|}
\cline { 2 - 4 } \multicolumn{1}{|c}{$\begin{array}{c}\text { Human } \\
\text { demography } \\
\text { and resource } \\
\text { balance }\end{array}$} & Hypothesis & $\begin{array}{l}\text { Increased demography, packing } \\
\text { threshold was reached. }\end{array}$ & $\begin{array}{l}\text { No-Intensification } \\
\text { Ihreshold was not reached. }\end{array}$ \\
\hline \multirow{2}{*}{$\begin{array}{c}\text { Faunal } \\
\text { Expectations }\end{array}$} & $\begin{array}{l}\text { Resource } \\
\text { exploitation }\end{array}$ & $\begin{array}{l}\text { Best ranked resources depressed. } \\
\text { Diet Breadth: Low ranked preys are } \\
\text { now incorporated to the diet. }\end{array}$ & $\begin{array}{l}\text { No clear evidences of resource } \\
\text { depression. } \\
\text { Diet Breath: Some preys from specific } \\
\text { areas are now incorporated to the diet. }\end{array}$ \\
\cline { 2 - 5 } & $\begin{array}{l}\text { Big game } \\
\text { processing } \\
\text { (guanacos })\end{array}$ & $\begin{array}{l}\text { More processing in killing sites. } \\
\text { Only well ranked body parts are } \\
\text { transported to the residential sites. } \\
\text { More fragmentation in the bones for } \\
\text { grease extraction. }\end{array}$ & $\begin{array}{l}\text { No differential processing of the } \\
\text { preys. All body parts are present in the } \\
\text { assemblages. }\end{array}$ \\
\hline
\end{tabular}


Table 2 Taxonomic representation measure for subsistence resources recovered from archaeological sites of Diamante River Basin.

All taxa are measured in NISP, except for Rheidae eggshels that we only indicate presence (X) or absence (-)

\begin{tabular}{|c|c|c|c|c|c|c|c|c|c|}
\hline & \multicolumn{3}{|c|}{ Altoandino Desert } & \multicolumn{6}{|c|}{ Patagonia Desert } \\
\hline Taxon & $\begin{array}{c}\text { Laguna } \\
\text { Diamante } \\
4\end{array}$ & $\begin{array}{l}\text { Risco } \\
\text { de los } \\
\text { Indios }\end{array}$ & $\begin{array}{c}\text { El } \\
\text { Indígeno }\end{array}$ & $\begin{array}{c}\text { Cueva El } \\
\text { manantial }\end{array}$ & $\begin{array}{c}\text { El } \\
\text { Perdido } \\
4\end{array}$ & $\begin{array}{c}\text { El } \\
\text { perdido } \\
5\end{array}$ & $\begin{array}{c}\text { Alero } \\
\text { Montiel }\end{array}$ & Carrizalito & Potrerillos \\
\hline Bird indet. & - & - & 2 & - & - & - & 4 & 8 & - \\
\hline Medium size Bird indet. & 27 & - & - & - & - & - & - & - & - \\
\hline Charadriiformes indet. & 2 & - & - & - & - & - & - & - & - \\
\hline Anatidae indet. & 30 & - & - & - & - & - & - & - & - \\
\hline Anas sp. & 6 & - & - & - & - & - & - & - & - \\
\hline Anas platalea & 1 & - & - & - & - & - & - & - & - \\
\hline Anas specularioides & 1 & - & - & - & - & - & - & - & - \\
\hline Attagis gayi & 1 & - & - & - & - & - & - & - & - \\
\hline Choelephaga melanoptera & 1 & - & - & - & - & - & - & - & - \\
\hline Lophonetta specularioides & 1 & - & - & - & - & - & - & - & - \\
\hline Paseriforme Indet. & 1 & - & - & - & - & - & - & - & - \\
\hline Anseriformes indet. & 1 & - & - & - & - & - & - & - & - \\
\hline Suboscine indet. & 1 & - & - & - & - & - & - & - & - \\
\hline Rhea pennata & - & - & - & - & - & - & - & 1 & - \\
\hline Mammalia indet. & 320 & 255 & 10 & 34 & 9 & 23 & 50 & 19 & 7 \\
\hline Artiodactyla indet. & 24 & - & 9 & - & - & - & 4 & 1 & - \\
\hline Camelidae indet. & 13 & 35 & - & 11 & 1 & 11 & 23 & 4 & 3 \\
\hline Lama sp. & 161 & - & 10 & - & - & - & 42 & 8 & - \\
\hline Lama guanicoe & 83 & 49 & 22 & 12 & 3 & 7 & 37 & 3 & 1 \\
\hline Felis concolor & - & - & - & - & - & - & 1 & 2 & - \\
\hline Pseudalopex culpaeus & - & 1 & - & 3 & - & - & - & - & - \\
\hline Pseudalopex griseus & - & - & - & - & - & - & 1 & - & - \\
\hline Lagostomus maximus & - & - & - & - & - & - & 1 & - & - \\
\hline Lagidium viscacia & - & - & - & - & - & - & 7 & - & - \\
\hline Dasipodidae indet. & - & - & - & 2 & - & 1 & 4 & 4 & - \\
\hline Chaetophractus sp. & - & - & - & - & - & - & 2 & 4 & - \\
\hline Zaedyus sp. & 3 & - & - & - & - & - & 5 & - & - \\
\hline Indet. & 14539 & 1085 & 151 & 220 & 88 & 632 & 51 & 22 & 1 \\
\hline Total NSP & 15254 & 1428 & 204 & 282 & 101 & 674 & 237 & 78 & 8 \\
\hline Total NISP & 715 & 343 & 53 & 62 & 13 & 42 & 186 & 56 & 4 \\
\hline Dasipodidae Dermal bones & 11 & 3 & & 16 & & 27 & 16 & 17 & \\
\hline $\begin{array}{l}\text { Presence of Ostrich } \\
\text { eggshels }\end{array}$ & $x$ & - & - & $x$ & - & - & $x$ & $x$ & - \\
\hline
\end{tabular}


Table 3 Taxa present per sites in Altoandino and Patagonia desert. Black cells show presence.

\begin{tabular}{|c|c|c|c|c|c|c|c|c|c|c|c|}
\hline Desert & Arch. site. & 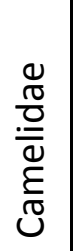 & 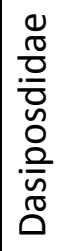 & 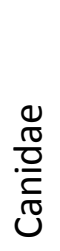 & $\begin{array}{l}\frac{0}{\pi} \\
\frac{\pi}{0} \\
\frac{0}{\nu} \\
\end{array}$ & $\begin{array}{l}\frac{0}{\pi} \\
\frac{\pi}{0} \\
\frac{\pi}{\alpha} \\
\frac{\pi}{\alpha}\end{array}$ & $\begin{array}{l}\frac{0}{\pi} \\
\frac{\pi}{0} \\
\frac{0}{0} \\
\frac{\pi}{0} \\
\frac{0}{0} \\
\frac{0}{U}\end{array}$ & 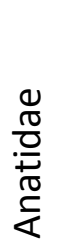 & 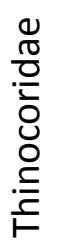 & 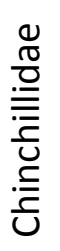 & $\frac{\sqrt{x}}{\frac{1}{2}}$ \\
\hline \multirow[t]{3}{*}{ Altoandino } & LD-4 & & & & & & & & & & 5 \\
\hline & Risco Indios & & & & & & & & & & 3 \\
\hline & El Indigeno & & & & & & & & & & 1 \\
\hline \multirow[t]{6}{*}{ Patagonia } & A.Montiel & & & & & & & & & & 5 \\
\hline & Carrizalito & & & & & & & & & & 4 \\
\hline & $\begin{array}{l}\text { C. } \\
\text { Manantial }\end{array}$ & & & & & & & & & & 3 \\
\hline & El Perd. 5 & & & & & & & & & & 2 \\
\hline & Potrerillos & & & & & & & & & & 1 \\
\hline & El Perd 4 & & & & & & & & & & 1 \\
\hline
\end{tabular}

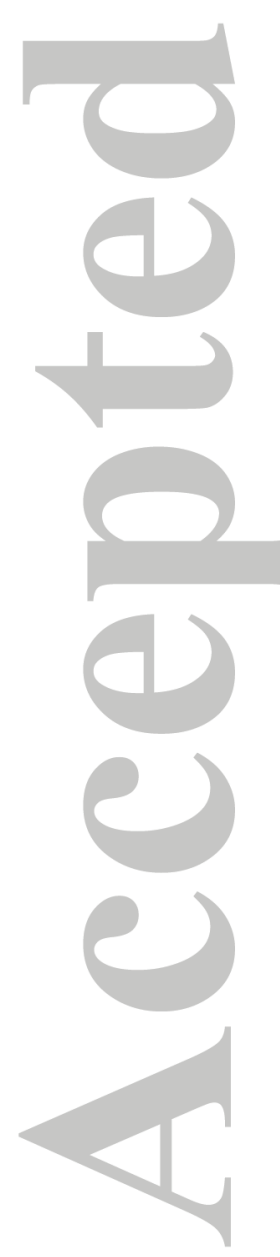


Table 4 Correlation values for density-mediated destruction (DMD) Marrow index and correlation values for FUI to NNISP- *Bones with high grease utility values are the: humerus, radius, ulna, femur, tibia, calcaneus and metapodials.

\begin{tabular}{|c|c|c|c|c|c|c|}
\hline & LD-S4 & RI & El & C. Manantial & A. Montiel & Carrizalito \\
\hline Meat Index & $\begin{array}{c}r_{s}=-0.28 \\
p=0.23\end{array}$ & $\begin{array}{c}r_{s}=-0.10 \\
p=0.66\end{array}$ & $\begin{array}{c}r s=-0.01 \\
p=0.95\end{array}$ & $\begin{array}{c}r s=-0.09 \\
p=0.7\end{array}$ & $\begin{array}{c}r s=-0.37 \\
p=0.12\end{array}$ & $\begin{array}{c}r s=-0.24 \\
p=0.32\end{array}$ \\
\hline Marrow Index & $\begin{array}{l}r s=0.5 \\
p=0.25\end{array}$ & $\begin{aligned} r s & =-0.88 \\
p & =0.01\end{aligned}$ & $\begin{aligned} r s & =0.18 \\
p & =0.69\end{aligned}$ & $\begin{array}{c}r s=0.22 \\
p=0.63\end{array}$ & $\begin{array}{c}r s=-0.09 \\
p=0.19\end{array}$ & $r s=0.08 ; p=0.9$ \\
\hline BMD Index & $\begin{aligned} r s & =0.25 \\
& =0.23\end{aligned}$ & $\begin{array}{c}r s=0.47 \\
p=0.01\end{array}$ & $\begin{array}{c}r s=0.14 \\
p=0.48\end{array}$ & $\begin{array}{l}r s=0.08 \\
p=0.06\end{array}$ & $\begin{array}{c}r s=0.22 \\
p=0.28\end{array}$ & $\begin{array}{c}r s=0.25 \\
p=0.23\end{array}$ \\
\hline NISP:MNE guanaco & 1,66 & 1,17 & 1,2 & 1,09 & 1,5 & 1,08 \\
\hline $\begin{array}{l}\text { NISP:MNE with high grease utility } \\
\text { values* }\end{array}$ & 1,4 & 1 & 1 & 1 & 1,15 & 1 \\
\hline
\end{tabular}

